УДК 581.192.2:[582.738]:543.544.6:543.635.226:543.645.6:581.144.9

\title{
ВОДОРАСТВОРИМЫЕ ПОЛИСАХАРИДЫ ТРАВЫ ЛЮЦЕРНЫ ПОСЕВНОЙ MEDICAGO SATIVA (FABACEAE) ФЛОРЫ КРАСНОЯРСКОГО КРАЯ
}

\author{
() К.И. Ровкина ${ }^{1,2 *}$, С.В. Кривощеков ${ }^{1,2}$, А.М. Гурьев ${ }^{1}$, М.С. Юсубов ${ }^{1,2}$, М.В. Белоусов ${ }^{1}$ \\ ${ }^{1}$ Сибирский государственный медицинский университет, Московский тракт, 2, \\ Томск, 634050 (Россия), e-mail: rki91@bk.ru \\ ${ }^{2}$ Национальный исследовательский томский политехнический университет, \\ пр. Ленина, 30, Томск, 634050 (Россия)
}

Трава люцерны посевной (Medicago sativa L.) уже долгие годы широко используется в народной медицине и при производстве различных биологически активных добавок. Помимо этого, люцерна - ценный кормовой представитель семейства бобовые, посевные площади которой в России достигают 2,3-2,5 млн га. Из надземной части люцерны посевной выделен с помощью водной экстракции $(\mathrm{pH}=9)$ и охарактеризован физико-химическими методами полисахаридный комплекс (ПСК). Определено содержание уроновых кислот - 13,1 $0,9 \%$, количественное содержание примесных веществ, таких как белок $-4,25 \pm 0,28 \%$, нуклеиновые кислоты $-0,0056 \pm 0,0003 \%$, минеральные примеси (зольность) $-3,45 \pm 0,18 \%$. Полученный ПСК был исследован методом ИК-спектроскопии. Охарактеризован мономерный состав ПСК методом хромато-масс-спектрометрии (мажорные моносахара - арабиноза, глюкоза и галактуроновая кислота). Изучено молекулярно-массовое распределение ПСК методом эксклюзионной хроматографии высокого давления и показано, что полисахаридный комплекс надземной части люцерны посевной состоит из трех компонентов с молекулярными массами $1100 \pm 60,16 \pm 2$ и $7 \pm 1$ кДа. Методом колоночной ионообменной хроматографии показано, что ПСК представляет собой смесь семи полисахаридов.

Ключевые слова: полисахаридный комплекс, люцерна посевная, Medicago sativa.

\section{Введение}

Среди культивируемых растений встречается немало видов, которые широко используются в народной медицине, но ввиду отсутствия научно-обоснованных данных о химическом составе и фармакологических свойствах еще не применяются в научной медицине. Настой люцерны применяют при заболеваниях желудочно-кишечного тракта в качестве противовоспалительного и улучшающего пищеварение средства. Кроме этого, площади, занимаемые люцерной посевной, в России достигают 2,3-2,5 млн га, что свидетельствует об обширной сырьевой базе. Во многих странах мира используется трава люцерны посевной для получения различных биологически активных добавок, таких как «Альфа Герб» (США), Medicago sativa spagyros (Германия), Антихолестерин Люцерна (Украина), Эраконд (Россия), Люцерна НСП (США). Однако биологически активные соединения данного растения, в особенности водорастворимые полисахариды, остаются малоизученными. Известно [1-6], что полисахариды высших растений могут обладать различ-

Ровкина Ксения Игоревна - лаборант-исследователь центра внедрения технологий; аспирант,

e-mail: rki91@bk.ru

Кривощеков Сергей Владимирович - младший научный сотрудник; аспирант, e-mail: ksv_tpu@mail.ru

Гурьев Артем Михайлович - руководитель центра внедрения технологий, e-mail: titan-m@mail.ru Юсубов Мехман Сулейман огль - заведующий кафедрой, e-mail: yusubov@mail.ru

Белоусов Михаил Валерьевич - заведующий кафедрой, e-mail:mvb63@mail.ru ными фармакологическими эффектами (противоопухолевая, иммуномодулирующая, антиоксидантная, гепатопротективная, противоязвенная и другие виды активности). В последнее время с развитием современных физико-химических методов эта группа биологически активных веществ стала доступна для изучения. Известны работы, посвященные оптимизации технологии получения полисахаридного комплекса из люцерны посевной, как по классиче-

\footnotetext{
* Автор, с которым следует вести переписку.
} 
ской методике [7], так и с применением ферментов [8]. Ранее описана и биологическая активность полисахаридов люцерны посевной, например в 2013 г. описана пролиферативная активность [9], а в 2014-м - гепатопротекторный эффект [10]. Целью нашей работы являлось выделение и изучение химического состава водорастворимых полисахаридов люцерны посевной, произрастающей в местах естественного обитания Ачинского района Красноярского края.

\section{Экспериментальная часть}

Объектом исследования являлся полисахаридный комплекс (ПСК), выделенный из надземной части люцерны посевной (Medicago sativa L.) (ЛП), заготовленной в фазу цветения в 2012-2013 гг. в Ачинском районе Красноярского края. После сбора надземная часть ЛП была высушена на воздухе, под навесом, при температуре $15-25^{\circ} \mathrm{C}$ в течение 5 суток. Исследовались образцы растительного сырья отдельно по годам сбора.

Общие аналитические методы. Измельченное воздушно-сухое сырье обрабатывали $70 \%$ кипящим этанолом течение 1 ч (отношение сырье : экстрагент $=1: 30$ ) для ингибирования ферментов (амилаз) и удаления низкомолекулярных и липофильных веществ. Далее проводили экстракцию водой, подщелоченной раствором натрия гидроксида до $\mathrm{pH}=9$ при соотношении сырье : экстрагент $1: 20$ в течение 2 ч на водяной бане $\left(\mathrm{t}=90^{\circ} \mathrm{C}\right)$ и периодическом помешивании. Для отделения сырья от водного извлечения использовали фильтрацию через тканевый фильтр. Полученное извлечение упаривали на лабораторном роторном испарителе Laborota 4001 efficient (Heidolph, Германия) при температуре $40{ }^{\circ} \mathrm{C}$. Для осаждения полисахаридов из водного раствора использовали $96 \%$ этанол в соотношении $1: 4$ (по объему). Осадок отстаивали при температуре $2-4{ }^{\circ} \mathrm{C}$ в течение 12 ч. Далее осадок полисахаридов центрифугировали (4400 об/мин в течение 10 мин) и растворяли в воде на магнитной мешалке при комнатной температуре в течение 2 ч. Раствор полисахаридов подвергали ультрафильтрации с целью удаления низкомолекулярных примесей на кассетах Viva Flow 200 MWCO 5000, давление на выходе 3 атм. После очистки раствор лиофильно высушивали в течение 24 ч на лабораторной установке SP Scientific 85 (Labconco, CША). Температура заморозки $-35^{\circ} \mathrm{C}$, давление 500 мбар. Рабочая температура $-1{ }^{\circ} \mathrm{C}$, давление 100 мкбар, температура конденсора $40{ }^{\circ} \mathrm{C}$. Экспериментально доказано, что применяемые параметры экстракции обеспечивают максимальный выход ПСК люцерны посевной [7]. Схема выделения полисахаридного комплекса из надземной части люцерны посевной (PS MS) представлена на рисунке 1.

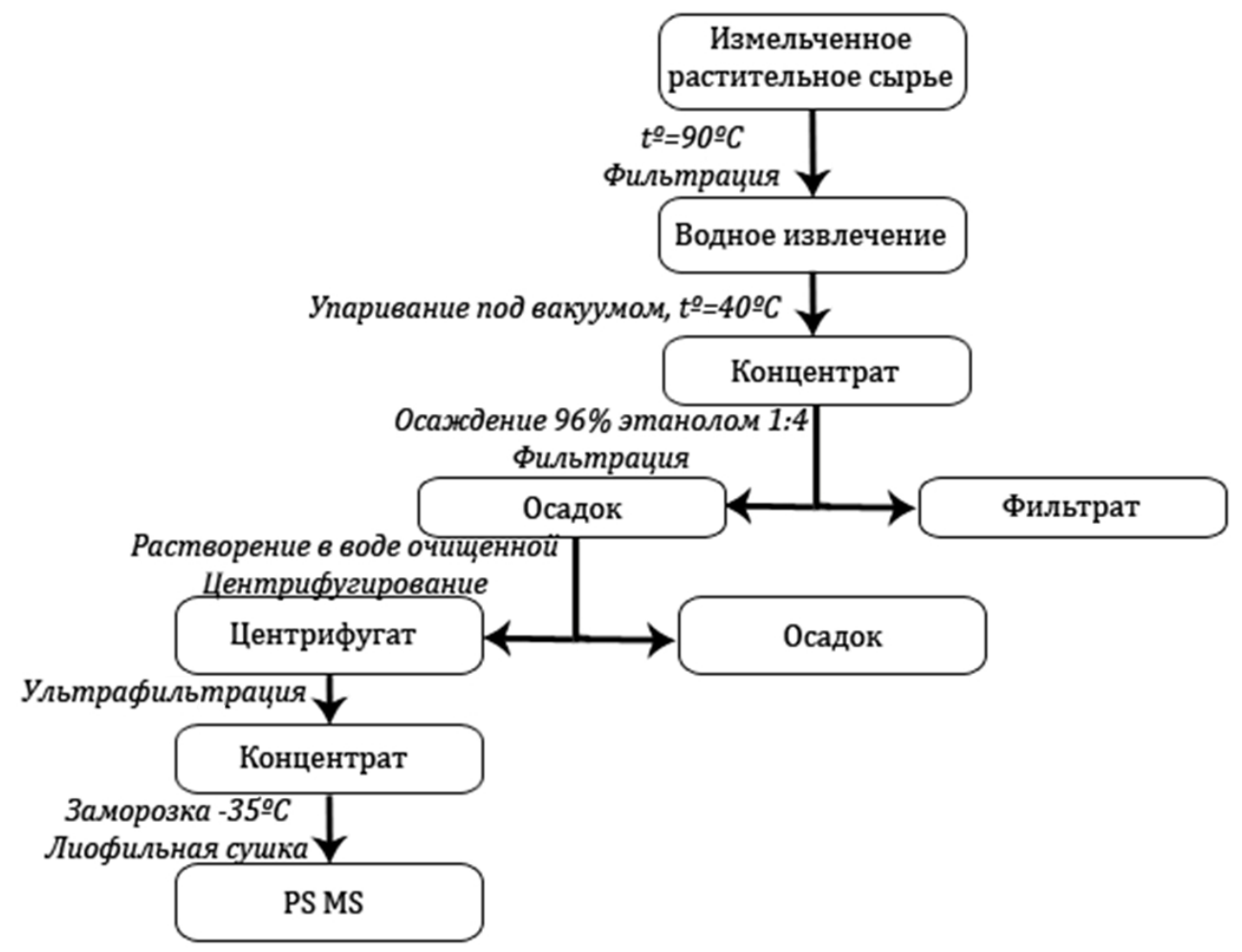

Рис. 1. Схема выделения ПСК из надземной части люцерны посевной 
Суммарное содержание сахаров устанавливали фенол-серным методом [11]. Количественное содержание уроновых кислот в ПСК определяли спектрофотометрическим модифицированным карбазолсерным методом [12]. Содержание уроновых кислот рассчитывали по градуировочному графику, построенному для D-галактуроновой кислоты в диапазоне концентраций 0,05-10 мг/мл. Для количественного определения низких концентраций белка использовали метод Лоури [12], нуклеиновых кислот - метод Спирина [14]. Для определения неорганических примесей нами была определена зольность ПСК [15].

ИК-спектры образцов полисахаридов записывали в таблетках $\mathrm{KBr}$ в диапазоне волновых чисел 400$4000 \mathrm{~cm}^{-1}$ на приборе ИК-Фурье спектрометр ФСМ-1201 («Инфраспек», Россия). Молекулярно-массовое распределение образцов определяли методом эксклюзионной хроматографии высокого давления [16] на жидкостном хроматографе Ultimate 3000 (Германия, Dionex), оснащенном насосом высокого давления LPG-3400SD (скорость потока 1 мл/мин, подвижная фаза - вода деионизированная), колонкой TSK $\mathrm{GMPW}_{\mathrm{XL}}, 300 \times 78$ мм, 13 мкм, термостатируемым колоночным отделением $\left(30{ }^{\circ} \mathrm{C}\right)$, дифференциальным рефрактометром Shodex RI-101 (температура ячейки $40{ }^{\circ} \mathrm{C}$ ). Для построения калибровочной прямой эксклюзионной колонки были использованы стандарты декстранов в интервале молекулярных масс от 1 до 5000 кДа. Калибровочная прямая построена в координатах $\lg \mathrm{Mw}=\mathrm{f}\left(\mathrm{t}_{\mathrm{R}}\right)$.

Для характеристики мономерного состава проводили гидролиз полисахаридов (навеска - 10 мг) $4 \mathrm{M}$ трифторуксусной кислотой $\left(100{ }^{\circ} \mathrm{C}, 5\right.$ ч), после чего гидролизат досуха упаривали на роторном испарителе, трижды добавляя метанол (порциями по 0,5 мл). Для перевода моносахаридов в аналитическую форму проводили силилирование N-триметилсилил имидазолом (ТМСИ) (Acros organics, США), для чего к остатку добавляли безводный пиридин (100 мкл) и ТМСИ (30 мкл), термостатировали 25 мин при $75^{\circ} \mathrm{C}$, охлаждали и экстрагировали триметилсилил-производные сахаров 0,5 мл гексана дважды. Идентификацию моносахаров вели по совпадению времен удерживания пиков на хроматограмме испытуемого раствора со временами удерживания пиков использованных стандартов (арабиноза, глюкоза, галактоза, манноза, рамноза, ксилоза, галактуроновая кислота, глюкуроновая кислота, фруктоза), а также по совпадению массспектров с библиотечными (NIST). Разделение силилированных образцов проводили на газовом хроматографе Agilent 7890A (США) на колонке HD-5 MS 30 м, внутренний диаметр капилляра 0,25 мм, скорость потока газа-носителя (Не) 1 мл/мин, в градиенте температур: $70{ }^{\circ} \mathrm{C}-2$ мин, далее $10{ }^{\circ} \mathrm{C} /$ мин (до $300{ }^{\circ} \mathrm{C}$ ), температура инжектора $280^{\circ} \mathrm{C}$, детектирование велось на масс-спектрометре Agilent 5975S (CША), ионизация электронным ударом, сканирование m/z 33-600, температура ионного источника $120^{\circ} \mathrm{C}$.

Для разделения ПСК надземной части ЛП на индивидуальные полисахариды был использован метод колоночной ионообменной хроматографии на DEAE-целлюлозе (в Cl-форме, емкость сорбента 0,9-1 мэкв/г, размер частиц 100-200 мкм). Навеску полисахарида (288 мг) растворяли в 5 мл воды очищенной, наносили на колонку объемом 103 см$^{3}$. В качестве подвижной фазы использовались растворы $\mathrm{NaCl}(0,01 ; 0,1 ; 0,2 ; 0,3 ; 0,4$; 1,0 моль/л) объемом по 500 мл, разделение выполняли при объемной скорости элюента 2 мл/мин, отбирая фракции по 15-25 мл. Определение наличия сахаров во фракциях проводили карбазол-серным методом [17]. Полученные фракции объединяли и концентрировали на ультрафильтрационной кассете Vivaflow 200 (Sartorius Stedium Biotech) 5000 MWCO. Сконцентрированные фракции лиофильно высушивали [18].

\section{Обсуждение результатов}

Выход ПСК из надземной части ЛП, заготовленной в 2013 г., составил 3,6 \pm 0,5\%, заготовленной в 2014 г. - 3,9 \pm 0,2\% в пересчете на абсолютно сухое сырье. Характеристика состава полученных полисахаридных комплексов ЛП представлена в таблице 1. Полученные данные показывают незначительные отличия между сырьем различных годов заготовки.

Таблица 1. Состав водорастворимого полисахаридного комплекса ЛП

\begin{tabular}{l|c|c}
\hline \multicolumn{1}{c|}{ Показатель } & \multicolumn{2}{|c}{ Содержание, \% (n=5 $\left.{ }^{*}\right)$} \\
\cline { 2 - 3 } & 2013 г. & $92,71 \pm 1,57$ \\
\hline Суммарное содержание сахаров & $94,19 \pm 1,05$ & $14,36 \pm 1,54$ \\
Содержание уроновых кислот & $13,11 \pm 0,90$ & $4,99 \pm 0,51$ \\
Содержание белка & $4,25 \pm 0,28$ & $0,0043 \pm 0,0004$ \\
Содержание нуклеиновых кислот & $0,0056 \pm 0,0003$ & $3,84 \pm 0,30$ \\
Зольность ПСК ЛП & $3,45 \pm 0,18$ & \\
\hline
\end{tabular}

\footnotetext{
$\mathrm{n}$ - число повторностей.
} 
В ИК-спектре полисахаридного комплекса люцерны посевной (рис. 2) наблюдается широкая интенсивная полоса поглощения в области 3200-3600 см-1, характерная для валентных колебаний гидроксильных групп. Также обнаружены полосы поглощения при 2850-3200 см-1 , обусловленные валентными и деформационными колебаниями С-Н связей. Но более информативной в ИК-спектрах полисахаридов является область от 850-1800 $\mathrm{cm}^{-1}$. Ее можно разделить на две составляющие:

1) 1200-1800 см ${ }^{-1}$, в которой наблюдаются полосы поглощения: при 1747 и $1609 \mathrm{~cm}^{-1}$, характерные для валентных колебаний метоксилированной (-COOR) и свободной (-COO-) карбоксильной группы кис-

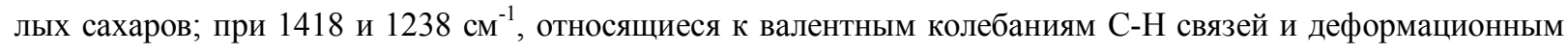
колебаниям С-О связей в остатках галактуроновой кислоты [19];

2) 850-1200 см${ }^{-1}$, которая, согласно литературным данным [20, 21], является областью «отпечатков пальцев» пектиновых веществ, где положение и интенсивность полос являются специфическими для пектиновых полисахаридов. В ИК-спектре ПСК люцерны посевной в данной области обнаружены полосы поглощения при $1147 \mathrm{~cm}^{-1}$, которые можно отнести к валентным колебаниям боковых групп С-ОН, при 1017 см (колебания кольцевых С-C связей) и при $1100 \mathrm{~cm}^{-1}$ (колебания гликозидных связей С-O-C полисахаридов).

На рисунке 3 представлена эксклюзионная хроматограмма ПСК люцерны посевной, из которой видно, что полисахаридный комплекс люцерны посевной состоит из трех компонентов со временем удерживания 5,624, 6,233 и 9,205 мин, что соответствуюет молекулярным массам $1100 \pm 60,16 \pm 2$ и $7 \pm 1$ кДа с относительным содержанием $91,8 \pm 4,3 ; 7,9 \pm 0,4$ и $0,25 \pm 0,03 \%$ соответственно. Асимметричность пика с $t_{R}$ 5,624 мин свидетельствует о наличии межмолекулярных взаимодействий в полисахаридах [22, 23].
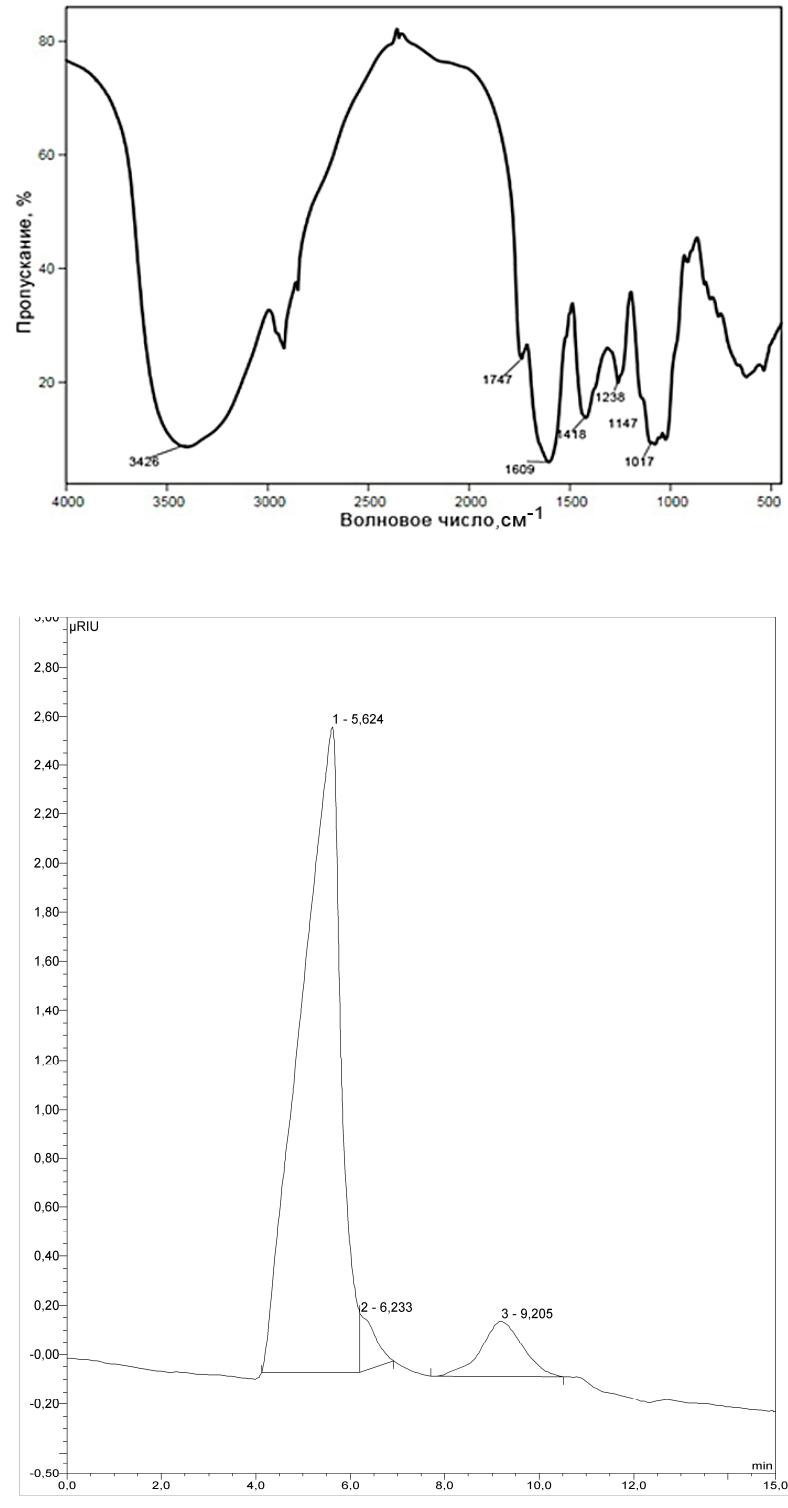

Рис. 2. ИК-спектр ПСК люцерны посевной

Рис. 3. Эксклюзионная хроматограмма ПСК люцерны посевной 
Из данных ГХ-МС анализа можно сделать вывод, что ПСК люцерны посевной содержит мажорные моносахариды: арабинозу, галактуроновую кислоту и глюкозу. В следовых количествах содержатся ксилоза и фруктоза. Относительное содержание остатков моносахаридов рассчитано методом простой нормировки и представлено в таблице 2 .

В результате разделения ПСК люцерны посевной, заготовленной в 2013 г., на колонке с DEAEцеллюлозой было получено семь фракций (рис. 4). Мажорными полисахаридами можно назвать PS MS-2 и PS MS-4, сумма которых превышает 50\% от суммы фракционированных полисахаридов (табл. 3).

Для определения молекулярной массы полученные фракции PS MS-2 и PS MS-4 были проанализированы методом эксклюзионной ВЭЖХ, результаты представлены в таблице 4.

По данным ГЖХ-МС установлено, что в гидролизатах PS MS-2 и PS MS-4 присутствуют глюкоза, арабиноза и галактуроновая кислота, однако их содержание различается, что отражено в таблице 5.

Таблица 2. Мономерный состав ПСК люцерны посевной по результатам ГХ-МС

\begin{tabular}{l|c|c}
\hline \multirow{2}{*}{ Моносахарид } & \multicolumn{2}{|c}{ Относительное суммарное содержание, \% } \\
\cline { 2 - 3 } & 2013 г. & 2014 г. \\
\hline Арабиноза & $43,6 \pm 2,21$ & $46,4 \pm 3,64$ \\
Галактуроновая кислота & $33,4 \pm 1,54$ & $28,2 \pm 1,27$ \\
Глюкоза & $11,6 \pm 0,66$ & $13,8 \pm 0,97$ \\
Галактоза & $6,1 \pm 0,21$ & $7,0 \pm 0,26$ \\
Фруктоза & $3,0 \pm 0,15$ & $3,6 \pm 0,19$ \\
Ксилоза & $2,6 \pm 0,12$ & $1,1 \pm 0,09$ \\
\hline
\end{tabular}

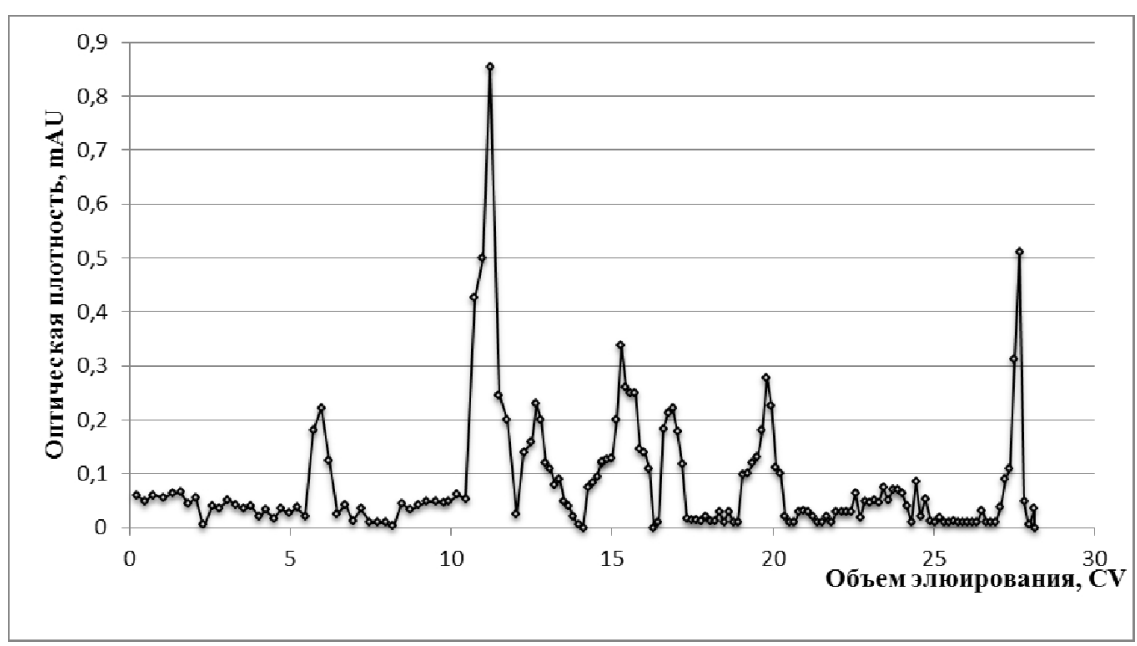

Рис. 4. Хроматограмма фракционирования ПСК люцерны посевной на ДЭАЭ-целлюлозе

Таблица 3. Фракционный состав ПСК люцерны посевной

\begin{tabular}{c|c|c}
\hline Фракция ПС & Относительное содержание, \% & Массовая доля от исходного ПСК, \% \\
\hline PS MS-1 & 9,86 & 6,2 \\
PS MS-2 & 27,75 & 19,5 \\
PS MS-3 & 9,47 & 6,1 \\
PS MS-4 & 24,55 & 16,4 \\
PS MS-5 & 7,99 & 5,5 \\
PS MS-6 & 8,0 & 5,2 \\
PS MS-7 & 12,38 & 9,8 \\
\hline
\end{tabular}

Таблица 4. Молекулярная масса индивидуальных ПС PS MS-2, PS MS-4

\begin{tabular}{c|c|c|c}
\hline \multicolumn{1}{c|}{ ПС } & $\mathrm{t}_{\mathrm{R}}$ мин & $\lg (\mathrm{MM})$ & ММ, кДа \\
\hline PS MS-2 & 5,074 & 6,018 & $1000 \pm 40$ \\
PS MS-4 & 5,690 & 5,776 & $600 \pm 2$ \\
\hline
\end{tabular}


Таблица 5. Мономерный состав индивидуальных ПС PS MS-2, PS MS-4

\begin{tabular}{l|c|c}
\hline \multirow{2}{*}{ Моносахарид } & \multicolumn{2}{|c}{ Относительное суммарное содержание, \% } \\
\cline { 2 - 3 } & PS MS-2 & PS MS-4 \\
\hline Арабиноза & $52,7 \pm 3,1$ & $49,4 \pm 2,7$ \\
Галактуроновая кислота & $14,6 \pm 0,9$ & $24,2 \pm 1,1$ \\
Глюкоза & $30,6 \pm 2,6$ & $25,1 \pm 1,8$ \\
\hline
\end{tabular}

\section{Bыводbl}

В результате проведенных исследований был определен выход комплекса водорастворимых полисаха-

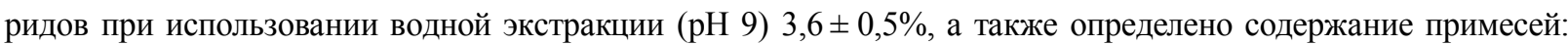
белок - 4,25 $\pm 0,28 \%$, нуклеиновые кислоты - 0,0056 $\pm 0,0003 \%$, минеральные примеси (зольность) $3,45 \pm 0,18 \%$. Содержание уроновых кислот $13,11 \pm 0,90 \%$. Полисахаридный комплекс представляет собой смесь семи полисахаридов, два из которых являются мажорными (PS MS-2 и PS MS-4). Достаточно высокий выход полисахаридов говорит о перспективности использования надземной части ЛП в качестве источника ПСК.

\section{Список литературы}

1. Yongxu Sun. Structure and biological activities of the polysaccharides from the leaves, roots and fruits of Panax ginseng // Carbohydrate Polymers. 2011. Vol. 85. Pp. 490-499.

2. Shibata H., Kimura-Takagi I., Nagaoka M. Properties of fucoidan from Cladosiphon okamuranus Tokida in gastric mucosal protection // BioFactors. 2000. Vol. 11. Pp. 235-245.

3. Yichun Sun. Biological activities and potential health benefits of polysaccharides from Poria cocos and their derivatives // International Journal of Biological Macromolecules. 2014. Vol. 68. Pp. 131-134.

4. Сафонова Е.А., Гурьев А.М., Разина Т.Г., Зуева Е.П., Ефимова Л.А., Лопатина К.А. Повышение эффективности химиотерапии с помощью фармакологически активных фракций, выделенных из полисахаридного комплекса аира болотного (Acorus calamus L.) // Российский биотерапевтический журнал. 2012. Т. 11. № 4. С. 55-58.

5. Х Хотимченко Ю.С., Ковалев В.В., Савченко О.В., Зиганшина О.А. Физико-химические свойства, физиологическая активность и применение альгинатов полисахаридов бурых водорослей // Биология моря. 2001. № 3. C. $151-162$.

6. Сафонова Е.А., Разина Т.Г., Зуева Е.П., Лопатина К.А., Ефимова Л.А., Гурьев А.М., Рыбалкина О.Ю., Хотимченко Ю.С. Перспективы использования полисахаридов растений в комплексной терапии злокачественных опухолей // Экспериментальная и клиническая фармакология. 2012. Т. 75. № 9. С. 42-47.

7. Марченко Р.Д., Санжиев А.Н., Кривощеков С.В. Влияние фракционного состава сырья и рН экстракции на эффективность выделения полисахаридного комплекса люцерны посевной (Medicago sativa L.) // Химия и химическая технология в XXI веке: материалы XVI Международной научно-практической конференции студентов и молодых ученых, посвященной 115-летию со дня рождения профессора Л.П. Кулёва. Томск, 2015. C. $288-290$.

8. Wang S., Dong X. \& Tong J. Optimization of enzyme-assisted extraction of polysaccharides from alfalfa and its antioxidant activity // International Journal of Biological Macromolecules. 2013. Vol. 62. Pp. 387-396.

9. Li J., Tang Y., Meng X. The proliferative effects of alfalfa polysaccharides on the mouse immune cells // Life Science Journal. 2013. Vol. 10(2). Pp. 868-873

10. Wang S., Dong X., Ma H., Cui Y., Tong J. Purification, characterisation and protective effects of polysaccharides from alfalfa on hepatocytes // Carbohydrate Polymers. 2014. Vol. 112. Pp. 608-614.

11. Dubois M., Gilles K.A., Hamilton J., Robers P.A., Smith F. Colorimetric method for determination of sugars and related substances // Analytical Chemistry. 1956. Vol. 28. Pp. 350-356

12. Bitter T., Muir H.M. A modified uronic acid carbazole reaction // Analytical Biochemistry. 1962. Vol. 4. Pp. 330-331.

13. Lowry O.H., Rosbrough A.L. et al. Protein measurment with the folin phenol reagent // Journal of Biological Chemistry. 1951. Vol. 193. Pp. 265-270.

14. Спирин А.С. Спектрофотометрическое определение суммарного количества нуклеиновых кислот // Биохимия. 1958. Т. 23. № 5. С. 656-662.

15. Государственная фармакопея. М., 1987. Т. 1.335 с.

16. Корж А.П., Белоусов М.В., Гурьев А.М., Юсубов М.С. Определение молекулярной массы полисахаридов Inula helenium L. // Новые достижения в химии и химической технологии растительного сырья : материалы V Всероссийской конференции с международным участием. Барнаул, 2012. С. 40-41.

17. Galambos J.T. The reaction of carbazole with carbohydrates: I. Effect of borate and sulfamate on the carbazole color of sugars // Analytical Biochemistry. 1967. Vol. 19. Pp. 119-132.

18. Ровкина К.И., Кривощеков С.В., Гурьев А.М. Фракционирование водорастворимых полисахаридов люцерны посевной (Medicago sativa L.) на DEAE-целлюлозе // Высокие технологии в современной науке и технике. Томск, 2014. С. 282-283. 
19. Kačuráková M., Capek P., Sasinková V., Wellner N., Ebringerová A. FT-IR study of plant cell wall model compounds: pectic polysaccharides and hemicelluloses // Carbohydrate Polymers. 2000. Vol. 43. Pp.195-203.

20. Kačuráková M., Mathlouthi M. FTIR and laser-Raman spectra of oligosaccharides in water: characterization of the glycosidic bond // Carbohydrate Research. 1996. Vol. 284(2). Pp. 145-157.

21. Kačuráková M., Belton P.S., Wilson R.H., Hirsch J., Ebringerová A. Hydration properties of xylan-type structures: An FT-IR study of xylooligosaccharides // Journal of the Science of Food and Agriculture. 1998. Vol. 77(11). Pp. 38-44.

22. Rinaudo M., Tinland B.J. Some problems in aqueous size-exclusion chromatography of synthetic polymer and biopolymer characterization // Journal of Applied Polymer Science. 1991. Vol. 48. P. 19.

23. Yoshio Kato, Takao Matsuda, Tsutomu Hashimoto. New gel permeation column for the separation of watersoluble polymers // Journal of Chromatography A. 1985. Vol. 332. Pp. 39-46.

Поступило в редакциюю 6 апреля 2016 г.

После переработки 22 марта 2017 г. 
Rovkina K.I. ${ }^{1,2 *}$, Krivoshchekov S.V. ${ }^{1,2}$, Guryev A.M. ${ }^{l}$, Yusubov M.S. ${ }^{1,2}$, Belousov M.V. ${ }^{l}$ WATER-SOLUBLE POLYSACCHARIDES OF HERBS OF SUCKLING SEEDING MEDICAGO SATIVA (FABACEAE) FLORA OF THE KRASNOYARSK TERRITORY

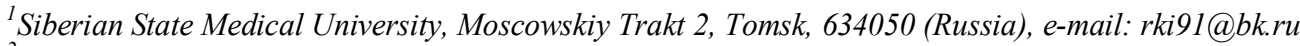

${ }^{2}$ National Research Tomsk Polytechnic University, pr. Lenina, 30, Tomsk, 634050 (Russia)

Alfalfa is a very high-quality perennial leguminous grass and has a long history of cultivation and application in traditional medicine in Russia. Alfalfa polysaccharides was extracted from alfalfa stems and leaves with distilled water in proportion to $1: 20$ and was characterized with different methods. The uronic acid content of the polysaccharides was quantificated colorimetrically with modified carbazole - sulfuric method $-13,1 \pm 0,9 \%$. The protein content of the polysaccharides was quantificated with Lowry protein assay $-4,25 \pm 0,28 \%$. The nucleinic acids contents was quantificated with Spirin's method $0,0056 \pm 0,0003 \%$. Ash-content (mineral impurities) was quantificated with gravimetrical method $-3,45 \pm 0,18 \%$. The description of IR spectrum was given. The monosaccharide composition of alfalfa polysaccharides was analysed by gas chromatography-mass spectrometry. The molecular weight was determined by high performance size-exclusion liquid chromatography. The crude alfalfa polysaccharides were fractionated by DEAE-cellulose chromatography. The sugar content of the fractions was assayed using the carbazole-sulphuric acid method. The alfalfa polysaccharides represents mix of seven polysaccharides.

Keywords: polysaccharide complex, alfalfa sowing, Medicago sativa.

\section{References}

1. Yongxu Sun. Carbohydrate Polymers, 2011, vol. 85, pp. 490-499.

2. Shibata H., Kimura-Takagi I., Nagaoka M. BioFactors, 2000, vol. 11, pp. 235-245.

3. Yichun Sun. International Journal of Biological Macromolecules, 2014, vol. 68, pp. 131-134.

4. Safonova E.A., Gur'ev A.M., Razina T.G., Zueva E.P., Efimova L.A., Lopatina K.A. Rossiiskii bioterapevticheskii zhurnal, 2012, vol. 11, no. 4, pp. 55-58. (in Russ.).

5. Khotimchenko Iu.S. Kovalev V.V., Savchenko O.V., Ziganshina O.A. Biologiia moria, 2001, no. 3, pp. 151-162. (in Russ.).

6. Safonova E.A., Razina T.G., Zueva E.P., Lopatina K.A., Efimova L.A., Gur'ev A.M., Rybalkina O.Iu., Khotimchenko Iu.S. Eksperimental'naia i klinicheskaia farmakologiia, 2012, vol. 75, no. 9, pp. 42-47. (in Russ.).

7. Marchenko R.D., Sanzhiev A.N., Krivoshchekov S.V. Khimiia i khimiche-skaia tekhnologiia v XXI veke: materialy XVI Mezhdunarodnoi nauchno-prakticheskoi konferentsii studentov i molodykh uchenykh, posviashchennoi 115-letiiu so dnia rozhdeniia professora L.P. Kuleva. [Chemistry and chemical technology in the 21 st century: materials of the XVI International Scientific and Practical Conference of Students and Young Scientists, dedicated to the 115th anniversary of the birth of Professor L.P. Kuleva]. Tomsk, 2015, pp. 288-290. (in Russ.).

8. Wang, S., Dong, X., Tong, J. International Journal of Biological Macromolecules, 2013, vol. 62, pp. 387-396.

9. $\quad$ Li J., Tang Y., Meng X. Life Science Journal, 2013, vol. 10(2), pp. 868-873.

10. Wang S., Dong X., Ma H., Cui Y., Tong J. Carbohydrate Polymers, 2014, vol. 112, pp. 608-614.

11. Dubois M., Gilles K.A., Hamilton J., Robers P.A., Smith F. Analytical Chemistry, 1956, vol. 28, pp. 350-356.

12. Bitter T., Muir H.M. Analytical Biochemistry, 1962, vol. 4, pp. 330-331.

13. Lowry O.H., Rosbrough A.L., et al. Journal of Biological Chemistry, 1951, vol. 193, pp. 265-270.

14. Spirin, A.S. Biokhimiia, 1958, vol. 23, no. 5, pp. 656-662. (in Russ.).

15. Gosudarstvennaia Farmakopeia. [State Pharmacopoeia]. Moscow, 1987, vol. 1, 335 p. (in Russ.).

16. Korzh A.P., Belousov M.V., Gur'ev A.M., Iusubov M.S. Novye dostizheniia v khimii i khimicheskoi tekhnologii rastitel'nogo syr'ia. Materialy V Vserossiiskoi konferentsii s mezhdunarodnym uchastiem. [New achievements in chemistry and chemical technology of plant raw materials. Materials of the V All-Russian Conference with International Participation]. Barnaul, 2012, pp. 40-41. (in Russ.).

17. Galambos, J.T. Analytical Biochemistry, 1967, vol. 19, pp. 119-132.

18. Rovkina K.I., Krivoshchekov S.V., Gur'ev A.M. Vysokie tekhnologii v sovremennoi nauke i tekhnike. [High technologies in modern science and technology]. Tomsk, 2014, pp. 282-283. (in Russ.).

19. Kačuráková M, Capek P, Sasinková V, Wellner N, Ebringerová A. Carbohydrate Polymers, 2000, vol. 43, pp.195203.

20. Kačuráková M., Mathlouthi M. Carbohydrate Research, 1996, vol. 284(2), pp. 145-157.

21. Kačuráková M., Belton P.S., Wilson R.H., Hirsch J., Ebringerová A. Journal of the Science of Food and Agriculture, 1998, vol. 77(11), pp. 38-44.

22. Rinaudo M., Tinland B.J. Journal of Applied Polymer Science, 1991, vol. 48, p. 19.

23. Yoshio Kato, Takao Matsuda, Tsutomu Hashimoto. Journal of Chromatography A, 1985, vol. 332, pp. $39-46$.

\footnotetext{
* Corresponding author.
} 